\title{
From Violence to Voting: War and Political Participation in Uganda CHRISTOPHER BLATTMAN Yale University
}

\begin{abstract}
$W$
hat is the political legacy of violent conflict? I present evidence for a link from past violence to increased political engagement among excombatants. The evidence comes from northern Uganda, where rebel recruitment generated quasiexperimental variation in who was conscripted by abduction. Survey data suggest that abduction leads to substantial increases in voting and community leadership, largely due to elevated levels of violence witnessed. Meanwhile, abduction and violence do not appear to affect nonpolitical participation. These patterns are not easily explained by conventional theories of participation, including mobilization by elites, differential costs, and altruistic preferences. Qualitative interviews suggest that violence may lead to personal growth and political activation, a possibility supported by psychological research on the positive effects of traumatic events. Although the generalizability of these results requires more evidence to judge, the findings challenge our understanding of political behavior and point to important new avenues of research.
\end{abstract}

$\mathbf{W}$ hat is the political legacy of a violent civil war? Can perpetrators and victims become productive citizens once the fighting stops? Policy makers are pessimistic. A recent World Bank report sees the individual impacts of civil war as so adverse that they lead to social disintegration (Collier et al. 2003). The French foreign minister recently spoke of young exsoldiers as "a time bomb that threatens stability and growth" (BBC 2007). A New York Times editorial lamented that such youth return as "damaged, uneducated pariahs" (Editorial, 2006). Meanwhile, reintegration experts worry that excombatants face a life of crime and banditry, and remain alienated and "at war" in their own minds (Richards et al. 2003; Spear 2006). If these commentators are correct, then the rebuilding of society may be all the more challenging and unlikely after war, and could contribute to the well-known "conflict trap" (Collier 2007).

Not all evidence is so gloomy. Psychologists consistently find that victims of violence are in general resilient, and a growing psychological literature finds that experiences of personal growth are more common than distress in the aftermath of violent trauma (Tedeschi and Calhoun 2004). A handful of studies also tie victimization by war violence to greater collective action. Wood (2003), for instance, argues that government violence in El Salvador prompted its victims to

\footnotetext{
Christopher Blattman is Assistant Professor, Department of Political Science, Yale University, 77 Prospect Street, P.O. Box 208209, New Haven, CT 06520-8209 (christopher.blattman@yale.edu).

I thank Jeannie Annan, my co-Investigator on the Survey of War Affected Youth (SWAY). For comments, I also thank Robert Bates, Khristopher Carlson, Macartan Humphreys, David Leonard, Dyan Mazurana, Edward Miguel, Betsy Levy Paluck, Gérard Roland, David Roodman, Cyrus Samii, Chris Udry, and Jeremy Weinstein, several anonymous referees, and seminar participants at Yale University, Columbia University, ECARES, and CGD. For data collection, I thank Roger Horton, Okot Godfrey, the SWAY field research assistants, AVSI Uganda, and UNICEF Uganda. Military escorts during data collection were provided by the Uganda People's Defense Force (UPDF). The survey was funded by grants from UNICEF (via AVSI Uganda), the John D. and Catherine T. MacArthur Foundation (via the UC Berkeley Human Rights Center), the Russell Sage Foundation, the International Peace Research Association Foundation, the UC Berkeley Center for African Studies, and the UC Berkeley Institute for Economic and Business Research.
}

support and even join opposition forces out of moral outrage, whereas Bellows and Miguel $(2006,2008)$ find that displacement and family deaths from war lead to greater political participation and awareness in Sierra Leonean households.

Little of this evidence, however, proves a causal link from violence to political engagement, and even less concerns the perpetrators. Yet, violence is endemic in the developing world; civil conflict has afflicted more than half of all nations since 1945, with one-fifth suffering ten or more years of war (Blattman and Miguel N.d.). In the burgeoning conflict literature, however, the impact of voting on violence receives more attention than the reverse (Snyder 2000; Wilkinson 2004).

I employ new data and a tragic natural experiment in northern Uganda to quantify the sociopolitical impacts of combat experiences and war violence. Patterns of rebel abduction during Uganda's twenty-year war appear to have generated nearly exogenous variation in recruitment. If so, causal estimates of its impact on later-life outcomes such as political participation can be identified.

The results defy expectations and suggest that forced recruitment leads to greater postwar political participation-a $27 \%$ increase in the likelihood of voting and a doubling of the likelihood of being a community leader among former abductees. Abduction, however, does not generally affect nonpolitical forms of social activity, suggesting that the effects of war on participation may be uniquely political. ${ }^{1}$

Of course, conscription simply represents a package of war experiences: violence, military training, indoctrination, time away, and so forth. Analysis of selfreported experiences suggests that exposure to violence, in particular, violence witnessed, accounts for most of the impact of abduction on participation. No other war experiences have similar explanatory power.

This finding is good news for policy makers in wartorn nations. For social scientists, however, it presents a puzzle: why would violence lead to positive

\footnotetext{
${ }^{1}$ Blattman and Annan (2008) use the same data and empirical strategy to assess the long-term economic and psychosocial impacts of abduction.
} 
political engagement? I argue that conventional explanations-ones that focus on the costs of voting, or elite mobilization-find little support in the data. Personal interviews with local leaders and former combatants, however, reveal narratives of personal transformation that echo a psychological literature on individual growth and activation after trauma (Tedeschi and Calhoun 2004). I explore the alternative empirical and theoretical links between violence and voting and set out an agenda for research in political behavior and psychology.

\section{WAR, ABDUCTION, AND POLITICS IN NORTHERN UGANDA}

In 1988, a spirit medium named Joseph Kony assembled the remnants of several failed insurgent groups from northern Uganda into a new force, the Lord's Resistance Army, or LRA. ${ }^{2}$ Locally, Kony is believed to possess great spiritual powers, and his stated goal is to seek a spiritual cleansing of the nation. Kony's movement, however, is also rooted in a long-standing political, economic, and ethnic divide. Following independence, northern peoples (including the Acholi, to which Kony and the LRA belong) dominated the military, whereas southerners dominated the commercial sector. For more than two decades, this martial power enabled a series of brutal northern dictators to govern the nation. In 1986, however, a young politician named Yoweri Museveni led a southern rebel force to overthrow the Acholi-dominated government. Several guerrilla forces in the north initially resisted Museveni's takeover, but for the most part settled for peace or were defeated by 1988 . The handful of fighters that would not settle for peace gathered under Kony to continue the fight.

Despite widespread antipathy for Museveni, the LRA attracted limited support from other Acholi, and the poverty and unpopularity of the movement led to nearly complete reliance on forced recruitment. From its earliest days, the rebels looted homes and abducted youth to obtain supplies and recruits. In 1994, the Sudanese government began supplying the LRA with supplies, weapons, and territory on which to build bases-support that enlarged and invigorated a small and weak LRA. Abduction from 1995 to 2004 was large scale and indiscriminate, with 60,000 to 80,000 youth estimated to have been taken by the LRA for at least a day (Annan, Blattman, and Horton 2006; Pham, Vinck, and Stover 2007). The majority were adolescent males, although men and women of all ages were commonly taken.

Twenty percent of male abductees did not return and, sadly, can be presumed perished (as few remain with the LRA). The remaining $80 \%$ escaped, were released, or were rescued after periods of 1 day to ten years. Roughly half of these "returnees" were demobilized by the Ugandan army (the UPDF), and two

2 This account is based on Allen (2005), Beber and Blattman (2008), Behrend (1999), Doom and Vlassenroot (1999), Finnström (2008b), Lamwaka (2002), and Omara-Otunnu (1994). in five returnees passed through a "reception center" that provided basic health services, family relocation, and reinsertion. In 2006, the Government of Uganda and the LRA reached a fragile truce. Peace talks broke down in 2008.

The two decades of instability and economic destruction in the north stand in stark contrast to the success and stability of the rest of Uganda. Outside Acholiland, violence has abated, infrastructure has expanded, HIV infection rates have fallen, and economic growth has been a robust $6 \%$ for the past decade (Government of Uganda 2007).

\section{DATA AND MEASUREMENT}

To assess the effects of combat and war violence on participation, this article compares the social and political participation of (exogenously) abducted and nonabducted youth in northern Uganda, as well as by specific war experiences within each group. Quantitative data come from Phase I of the Survey of War Affected Youth (SWAY), a representative survey of male youth (ages 14-30) in eight rural subcounties of the districts of Kitgum and Pader. Data were collected in 2005-06 by the author, a psychologist, and local research assistants.

To account for migration and mortality, the survey selected respondents from a sample frame of youth living in the region before the conflict. A total of 1,162 households were sampled from World Food Programme lists compiled in 2002 , and $93 \%$ of household heads were located and interviewed. Enumerators worked with household heads to develop a roster of all youth living in the household in 1996-a year chosen because it was easily recalled as the date of the first election since 1980.

A sample of 881 surviving male youth was drawn from these retrospective rosters. Nearly half of the youth had moved since 1996 and were tracked across the region. Surveyors located 741 , or $84 \%$. Former abductees were oversampled, with 462 interviewed in total. Absentee questionnaires were conducted with the families of young men that had died or were not found to correct for observable determinants of attrition. ${ }^{3}$ Survey summary statistics are listed in Table 1.

\section{Measuring Participation}

The survey includes three indicators of political participation. First, two weeks prior to the survey a national referendum was held on the question of opening Uganda to multiparty politics. ${ }^{4}$ Forty-six percent of survey respondents older than age 18 say they Voted

\footnotetext{
${ }^{3}$ There are two types of unfound youth: absentees that could not be tracked down, and those that did not return from abduction. Enumerators interviewed the families of all but about 11 absentees, and virtually all were reported to be engaged in work or school. Those that did not return from abduction comprise $20 \%$ of all abductees, $95 \%$ of which can be presumed perished given the small number of abductees still with the armed group.

4 This referendum asked voters: "Do you agree to open up the political space to allow those who wish to join different organizations/parties to do so to compete for political power?"
} 


\begin{tabular}{|c|c|c|c|c|c|c|c|}
\hline & \multicolumn{2}{|c|}{ All Youth } & \multicolumn{2}{|c|}{ Abducted Only } & \multicolumn{2}{|c|}{ Nonabd Only } & \multirow[b]{2}{*}{ Obs } \\
\hline & Mean & SD & Mean & SD & Mean & SD & \\
\hline \multicolumn{8}{|l|}{ War Experiences } \\
\hline Months abducted (total) & & & 9.3 & [16.2] & & & 741 \\
\hline Age abducted & & & 15.3 & [4.7] & & & 462 \\
\hline Violent acts total (of 25) & 7.9 & [4.7] & 11.0 & [4.6] & 5.2 & [2.9] & 737 \\
\hline Violent acts witnessed (of 6) & 3.0 & {$[1.7]$} & 3.9 & {$[1.5]$} & 2.2 & {$[1.5]$} & 739 \\
\hline Violent acts on family (of 5) & 2.1 & {$[1.4]$} & 2.2 & {$[1.4]$} & 2.0 & {$[1.4]$} & 739 \\
\hline Violent acts received (of 6) & 2.1 & {$[1.8]$} & 3.3 & {$[1.6]$} & 1.0 & {$[1.2]$} & 739 \\
\hline Violent acts perpetrated (of 9) & .7 & {$[1.4]$} & 1.5 & {$[1.8]$} & .1 & {$[.3]$} & 738 \\
\hline Leadership position (indicator) & & & .09 & {$[.29]$} & & & 462 \\
\hline Carried own firearm (indicator) & & & .32 & {$[.47]$} & & & 462 \\
\hline Passed through reception center & & & .39 & {$[.49]$} & & & 462 \\
\hline Received NGO services & & & .22 & [.42] & & & 462 \\
\hline \multicolumn{8}{|l|}{ Sociopolitical Indicators } \\
\hline Voted in 2005 (if 18 or older) & .46 & {$[.50]$} & .51 & {$[.50]$} & .40 & [.49] & 533 \\
\hline Community mobilizer & .051 & [.22] & .072 & {$[.26]$} & .032 & {$[.18]$} & 741 \\
\hline Political employment & .007 & {$[.08]$} & .011 & {$[.11]$} & .003 & {$[.06]$} & 741 \\
\hline Any community group member & .42 & [.49] & .43 & {$[.50]$} & .41 & {$[.49]$} & 741 \\
\hline Peace group member & .06 & {$[.24]$} & .07 & {$[.26]$} & .05 & {$[.21]$} & 741 \\
\hline Water committee member & .016 & [.12] & .009 & {$[.10]$} & .021 & {$[.14]$} & 741 \\
\hline Cultural group member & .16 & {$[.36]$} & .17 & {$[.37]$} & .15 & {$[.36]$} & 741 \\
\hline Sporting group or team member & .11 & [.31] & .08 & {$[.27]$} & .13 & {$[.33]$} & 741 \\
\hline Farmer's cooperative member & .11 & [.31] & .11 & [.32] & .10 & {$[.31]$} & 741 \\
\hline School club/committee member & .06 & {$[.23]$} & .06 & {$[.24]$} & .05 & {$[.22]$} & 741 \\
\hline Church or bible group member & .18 & {$[.38]$} & .17 & {$[.38]$} & .18 & {$[.38]$} & 741 \\
\hline Attends church & .78 & [.41] & .77 & {$[.42]$} & .79 & [.41] & 741 \\
\hline Volunteer & .05 & [.21] & .06 & {$[.23]$} & .04 & {$[.20]$} & 741 \\
\hline Disobeys elders & .07 & {$[.25]$} & .08 & {$[.27]$} & .06 & {$[.23]$} & 741 \\
\hline $\begin{array}{l}\text { Bottom quartile of prosocial } \\
\text { distribution }\end{array}$ & .23 & [.42] & .18 & {$[.38]$} & .27 & {$[.44]$} & 741 \\
\hline Physical fight & .07 & {$[.25]$} & .07 & {$[.25]$} & .07 & {$[.25]$} & 741 \\
\hline Ever quarrelsome & .05 & {$[.21]$} & .03 & {$[.17]$} & .06 & {$[.24]$} & 741 \\
\hline Ever threatens to hurt others & .02 & {$[.14]$} & .03 & {$[.17]$} & .01 & {$[.11]$} & 741 \\
\hline
\end{tabular}

in the 2005 referendum, a rate comparable to national turnout levels. Second, $5 \%$ of youth report that they are a Community mobilizer-elected members of the community who are responsible for organizing the community for daily or weekly meetings. ${ }^{5}$ Finally, four respondents $(.4 \%)$ hold a Political job, such as a village councilperson.

The survey also sought indicators of community participation. Forty-two percent report Membership in any community group, including peace groups $(6 \%)$, water management committees $(1.6 \%)$, cultural groups (16\%), sports teams (11\%), farmer's cooperatives $(11 \%)$, school clubs and committees $(6 \%)$, and church or bible study groups (18\%). Seventy-eight percent also Attend church regularly, and 5\% of youth Volunteer for a community organization.

Last, the survey measured self-reported prosocial and aggressive behaviors. Acholi culture stresses obe-

\footnotetext{
5 The mobilizer is the most common form of youth leadership and is an unpaid community service. Every few years, communities hold a meeting and solicit nominations. Nominees give a short speech and are elected by a show of hands.
}

dience to elders, and $7 \%$ indicated that they Disobey elders. The survey also measured 11 self-reported prosocial behaviors (e.g., enjoying working with peers, or being helpful to the community), and we construct an indicator for those in the Bottom quartile of the prosocial distribution. ${ }^{6}$ Finally, the survey asked whether respondents had been in a Physical fight in the past six months (7\%), whether they were Ever quarrelsome (5\%), and whether they Ever threatened to hurt others $(2 \%)$.

\section{Measuring War Experiences}

More than two in five male youth reported an $A b$ duction of any length. Many of these abductions were short, especially among abductees younger than 11 or older than 20. Such youth were often released after giving directions or carrying loot (Beber and Blattman

\footnotetext{
${ }^{6}$ The psychosocial survey questions are based on an adapted version of the Northern Ugandan Child and Youth Psychosocial Adjustment Scale (Loughry and MacMullin 2002)
} 
2008). Months Abducted ranged from 1 day to 10 years, averaging 9.3 months for a youth's longest abduction.

The LRA routinely used violence to intimidate and control civilians and abductees. To gauge respondents' levels of exposure to violence, the survey asked about 25 of the most common Violent acts experienced, including 6 acts witnessed, 6 received, 8 perpetrated by the respondent, and 5 inflicted on family members of the respondent by the LRA. ${ }^{7}$ The average abductee reported 11 different violent acts versus nonabductees' 5.2 acts. Most youth, for example, witnessed killings, experienced their homes being raided, or took cover from gunfire. Among the abducted, forced labor, thrashings, and imprisonment were commonplace. Attempts to escape were punished with beatings or death, a sentence other abductees were often forced to carry out with machetes or clubs. Initiation to the LRA also involved forced violence: $25 \%$ of abductees were made to harm or kill a civilian, and $23 \%$ were made to desecrate dead bodies-a deeply held taboo. Finally, $13.5 \%$ of abductees report being forced to beat or kill family or friends. Such violence served to break down a youth's defenses, desensitize him to violence, and dissuade him from escape (Beber and Blattman 2008).

Other war experiences recorded include indicators for whether the youth held a Leadership position or rank (9\%), ever Carried his own firearm (32\%), and whether he Passed through a reception center (39\%). Such centers were set up by local and international nongovernmental organizations (NGOs) after 1999 to receive youth returning from long abductions. Just $22 \%$ of abductees Received services from NGOs after returning home.

\section{Qualitative Data}

Following the survey and preliminary quantitative analysis, in 2007, I conducted semistructured interviews to explore the meaning and validity of the sociopolitical survey results. Interviews were conducted in three of the eight enumeration areas and included all survey respondents recorded as community mobilizers or having political jobs, all former abductees holding any rank, as well as a random sample of 20 respondents (half of whom voted in the 2005 referendum and half of whom did not). Interviews began with a repeat of the abduction and sociopolitical modules of the questionnaire, whereupon respondents were asked to elaborate on their closed-ended answers to explore key themes, including reasons for voting/not voting, the history of group participation and community leadership,

\footnotetext{
${ }^{7}$ The survey recorded an indicator for ever experiencing each act and each index is a sum of these indicators. Acts received include gunfire, forced labor, beatings, armed attacked, being tied up, and receiving a war. Acts witnessed include regular gunfire, beatings or torture, attacks or battles, killings, massacres, rape, and the torching of occupied homes. Acts perpetrated include beating a civilian, beating family or friends, killing a soldier, killing a civilian, killing family or friends, forcible sex, and abuse of dead bodies. Violence on family includes abducted parent, other abducted family, family member with war injury, violent death of a parent, and violent death of other family.
}

and reasons for/for not becoming a particular group member or community leader. ${ }^{8}$

Also interviewed in a less structured fashion were five reception center workers, six local political operatives, and two poll workers from the same three enumeration areas. These interviews focused on the role of formerly abducted youth in local politics (without revealing the positive association between abduction and participation).

Furthermore, prior to the survey in 2005 , I conducted two months of unstructured interviews with approximately 120 youth (including 80 abductees), plus more than 60 community members and leaders. The interviews focused on abduction patterns, LRA organization, and return and reintegration experiences. Interviews aimed to understand the conduct of the war, investigate the validity of the causal identification strategy, and develop reintegration metrics and hypotheses. Interview subjects were typically contacted through community leaders and reception center staff. fifteen former LRA junior officers (e.g., a lieutenant) were also purposefully located via these channels.

Finally, concurrent with the survey, a psychologist and a local social worker conducted systematic, semistructured interviews and psychosocial assessments of a nonrandom subsample of 30 youth and their families. The details of this qualitative psychosocial study are reported in Annan, Brier, and Aryemo (2008), and relevant results are highlighted in this article.

\section{THE IMPACT OF ABDUCTION ON PARTICIPATION}

\section{Empirical Strategy}

Estimating the impacts of military service and war violence is a difficult task. Combatants are usually unlike noncombatants in unobservable ways, and so any comparison will conflate the impacts of war with preexisting differences that led the youth to join or be selected by the armed group. This is especially true if the characteristics associated with being a combatant (e.g., poverty, social exclusion, or malleability) are traits that also affect social consciousness or political activity.

One solution is the counterfactual approach, where a relevant control group is found for recruits. The estimated impact, however, is only as reliable as the counterfactual. Causal estimates will be unbiased only when recruitment is "conditionally unconfounded" or exogenous-that is, when all selection is on observed traits (Imbens 2004; Rosenbaum and Rubin 1983; Rubin 1978).

\footnotetext{
${ }^{8}$ Questionnaires are available at www.sway-uganda.org or by request. Relevant modules include Sections VII (Community Involvement \& Political Attitudes) and IX (Abduction and Return Experiences). The interview was predicated as a follow-up of survey quality and responses, typically with the original enumerator present. Additional topics explored included war and abduction experiences, voter registration status, the qualities of good leaders, election processes, and the role of former abductees in the community and community politics.
} 
In most wars, such stringent conditions would not hold. Evidence from Uganda, however, suggests that the most common types of selection into armed groups are not present in the case of the LRA. First, volunteering (or self-selection) into the LRA was virtually unknown. What few volunteers did exist tended to join before 1991, and most come from a neighboring district, Gulu (and so do not influence this article's sample).

Second, interviews with the leaders of LRA raiding parties suggest that by neither design nor accident did they abduct a select group of youth. From their Sudanese bases, rebels ventured into Uganda for weeks at a time in groups of roughly 15 fighters. Raiding parties had two aims: ambushing government forces and raiding homesteads along their path for food and recruits. Abduction targets tended to be unplanned and arbitrary, and homesteads were raided regardless of wealth or makeup. Typical of East Africa, rural Acholi households live in relatively isolated homesteads in their fields, arrangements that made them particularly vulnerable to LRA raids. Rebels usually invaded such homesteads at night, abducting all able-bodied people to carry looted goods. These abduction parties were under instruction to release only young children and older adults, but to keep all adolescent and young adult males.

The data support these claims. The survey gathered data on prewar household wealth (including land and livestock) and parent's education, occupation, and death-traits that are believed to be reliable predictors of participation in armed groups in Africa (e.g., Cohn and Goodwin-Gill 1994; Honwana 2005; Humphreys and Weinstein 2008). If we compare the abducted and nonabducted along such prewar traits, we observe little difference in conditional mean differences at even the $10 \%$ significance level (Table 2, Column 1). Abducted youth differ only by year of birth (as expected) and prewar household size. ${ }^{9}$

These same household traits, however, help predict participation in a voluntary government militia, implying that if abduction were associated with these prewar traits we would have the statistical power to observe it. Five percent of youth were current or past militia members. A comparison of prewar traits shows that militia members came from poorer and more agricultural households (Table 2, Column 2), and collectively, the prewar covariates strongly predict government militia membership-the effects are larger than in the abduction case and jointly significant at the $5 \%$ level.

A remaining concern is selective attrition. There are two main types of "attritors": nonsurvivors and unfound migrants. The $84 \%$ tracking success rate meets or exceeds the rates achieved by several "goldstandard" youth tracking surveys in poor countries

\footnotetext{
9 The significance is driven by households greater than 25 in number, perhaps because small bands of raiders were hesitant to raid large, difficult-to-control groups. Otherwise, differences in the distributions of predicted abduction probabilities among abducted and nonabducted youth are driven by year and location of birth alone. In a logit regression of abduction on prewar traits, omission of household traits does not affect the distribution of the predicted probabilities, and they are jointly not significance $(p=.18)$.
}

(Hamory and Miguel 2006; Thomas, Frankenberg, and Smith 2001). Also, similar proportions of abducted and nonabducted youth were found $(29.7 \%$ vs. $28.3 \%)$. Even so, differential attrition patterns raise concern: nonabducted youth are more like to have migrated and gone unfound, whereas abductees are uniquely likely to have been abducted and not returned (and can be assumed perished given the small number of abductees still with the LRA). Estimates of the impact of abduction will be biased if qualities that determine migration or survival also shape political action.

To correct for attrition on observables, we collected demographic data and data on current activities and well-being from the surviving family members. Following Fitzgerald, Gottschalk, and Moffitt (1998), these data were used to calculate attrition probabilities, and regression estimates are weighted by the inverse of these attrition probabilities to eliminate bias from attrition on observed traits.

\section{Results}

Assuming conditional unconfoundedness, consistent estimates of the causal impact of abduction can be calculated using an index model such as a logit, weighted by a nonparametric estimate of the selection probability, or propensity score (Hirano, Imbens, and Ridder 2003). ${ }^{10}$ The results are displayed in Table 3.

To begin, abduction leads to an 11.0 percentage point increase in the probability a youth older than 18 voted in the 2005 referendum (Column 2), significant at the $1 \%$ level. Because just $40 \%$ of eligible nonabducted youth voted (Column 1), this ATE represents a 27\% increase in voter turnout (Column 3).

Abduction also leads to a 3.4 percentage point increase in the likelihood that a youth is a community mobilizer, significant at the $1 \%$ level. Just $3 \%$ of nonabducted youth are leaders, and so the impact of abduction represents a $106 \%$ increase in levels of leadership.

Abduction is also associated with a $190 \%$ increase in the likelihood of holding a political job such as a community council member or appointee. The estimate, however, is not statistically significant due to sample size: only four respondents reported such employment, three of whom are former abductees. But the direction and magnitude of the result is consistent with the other political results.

\footnotetext{
${ }^{10}$ In this case, $Y^{*}$ is a latent variable describing an individual $i$ 's propensity for participation, observed as a binary outcome, $Y$. The treatment effect, $\tau$, can be estimated by the following regression:

$$
\mathrm{P}\left(Y_{i}=1\right)=\boldsymbol{\Phi}\left(\tau \cdot T_{i}+X_{i}^{S} \cdot \beta_{1}\right)
$$

where the treatment (i.e., abduction) indicator $T$ equals 1 if youth $i$ was abducted, and the $X^{S}$ are the subset of observed covariates $X$ that are significantly correlated with $Y$, conditional on treatment. The weights used are

$$
\omega_{i}=\omega\left(T_{i}, v_{i}, \rho_{i}\right)=\rho_{i} \cdot \pi_{i} \cdot\left(\frac{T_{i}}{\hat{e}\left(v_{i}\right)}+\frac{1-T_{i}}{1-\hat{e}\left(v_{i}\right)}\right),
$$

where $\rho_{i}$ and $\pi_{i}$ are sampling and attrition weights, and $\hat{e}\left(v_{i}\right)$ is a nonparametric estimate of the propensity score. The $v_{i}$ are the subset of the covariates $X_{i}$ that have substantial correlation with the treatment.
} 


\begin{tabular}{|c|c|c|}
\hline \multirow[b]{3}{*}{ Pretreatment Covariate } & (1) & $(2)$ \\
\hline & \multicolumn{2}{|c|}{ Difference in Conditional Means } \\
\hline & $\begin{array}{l}\text { Abducted versus } \\
\text { Nonabducted Youth }\end{array}$ & $\begin{array}{c}\text { Militia versus } \\
\text { Nonmilitia Members }\end{array}$ \\
\hline Year of birth ${ }^{\dagger}$ & $\begin{array}{l}1.27 \\
{[.51]^{* *}}\end{array}$ & $\begin{array}{l}2.31 \\
{[.65]^{* * *}}\end{array}$ \\
\hline Indicator for father a farmer ${ }^{\dagger}$ & $\begin{array}{c}-.01 \\
{[.02]}\end{array}$ & $\begin{array}{c}.05 \\
{[.04]}\end{array}$ \\
\hline Household size in $1996^{\dagger}$ & $\begin{array}{c}-1.51 \\
{[.32]^{* * *}}\end{array}$ & $\begin{array}{l}1.32 \\
{[.54]^{* *}}\end{array}$ \\
\hline Landholdings in $1996^{\dagger}$ & $\begin{array}{c}-1.46 \\
{[2.72]}\end{array}$ & $\begin{array}{c}-7.12 \\
{[4.28]}\end{array}$ \\
\hline Indicator for top $10 \%$ of landholdings ${ }^{\dagger}$ & $\begin{array}{c}-.02 \\
{[.03]}\end{array}$ & $\begin{array}{l}-.12 \\
{[.05]^{* *}}\end{array}$ \\
\hline Cattle in $19966^{\dagger}$ & $\begin{array}{l}6.21 \\
{[4.98]}\end{array}$ & $\begin{array}{l}-4.51 \\
{[3.51]}\end{array}$ \\
\hline Other livestock in $1996^{\dagger}$ & $\begin{array}{l}2.07 \\
{[1.66]}\end{array}$ & $\begin{array}{l}-1.94 \\
{[2.38]}\end{array}$ \\
\hline Indicator for plow ownership in $1996^{\dagger}$ & $\begin{array}{c}-.01 \\
{[.04]}\end{array}$ & $\begin{array}{l}-.06 \\
{[.04]}\end{array}$ \\
\hline Indicator for uneducated father & $\begin{array}{l}.02 \\
{[.02]}\end{array}$ & $\begin{array}{l}-.12 \\
{[.04]^{* * *}}\end{array}$ \\
\hline Father's years of schooling & $\begin{array}{c}-.06 \\
{[.30]}\end{array}$ & $\begin{array}{c}.41 \\
{[.43]}\end{array}$ \\
\hline Indicator for uneducated mother & $\begin{array}{c}-.01 \\
{[.04]}\end{array}$ & $\begin{array}{l}.05 \\
{[.10]}\end{array}$ \\
\hline Mother's years of schooling & $\begin{array}{c}-.12 \\
{[.34]}\end{array}$ & $\begin{array}{c}-.14 \\
{[.65]}\end{array}$ \\
\hline Indicator for paternal death before 1996 & $\begin{array}{l}.03 \\
{[.05]}\end{array}$ & $\begin{array}{l}.05 \\
{[.11]}\end{array}$ \\
\hline Indicator for maternal death before 1996 & $\begin{array}{l}.02 \\
{[.02]}\end{array}$ & $\begin{array}{c}-.03 \\
{[.03]}\end{array}$ \\
\hline Indicator for orphaning before 1996 & $\begin{array}{c}-.02 \\
{[.02]}\end{array}$ & $\begin{array}{c}-.01 \\
{[.02]}\end{array}$ \\
\hline \multicolumn{3}{|c|}{$\begin{array}{l}\text { Notes: Robust standard errors in brackets, clustered by location. } \\
\text { All estimates weighted by inverse sampling probabilities and inverse attrition probabilities. } \\
\text { *Significant at } 10 \% \text {; **significant at } 5 \% \text {; ***significant at } 1 \% \text {. } \\
\dagger \text { Mean differences include data from unfound and nonsurviving youth, and omit inverse attrition } \\
\text { weights. } \\
\ddagger \text { The unconditional difference is a simple difference in means, whereas the conditional difference is } \\
\text { the coefficient on abduction from a weighted least squares regression of the covariate on abduction } \\
\text { and all other pretreatment covariates. }\end{array}$} \\
\hline
\end{tabular}

Turning to others forms of community participation, the causal impacts of abduction on various forms of group membership are either small or not statistically significant. Participation in a sporting organization is lower among abductees, although the result is only significant at the $10 \%$ level. Only in one instance, peace groups, is there a significant impact of abduction. Peace groups are clubs of youth that stage cultural dances, dramatic presentations, debates, and talks, often with peace-building or reconciliation themes, and abducted youth are nearly twice as likely to be members $(92 \%)$.

Finally, there is little evidence of heightened asocial or aggressive behavior among abductees. Abductees are slightly less likely to report that they engaged in a fight or exhibit antisocial behavior, but are more likely to report that they disobey elders, threaten others, or are quarrelsome. None of these results are statistically significant. One risk, of course, is that hostile attitudes and behaviors are systematically underreported, thus increasing standard errors and biasing coefficients downward (especially if measurement error is higher among abductees). Nonetheless, even underreporting of a grand magnitude-such as two in three youth failing to report aggressiveness-would still imply that aggression is small in absolute terms.

All estimates are robust to alternative specifications, including the removal of the control variables, the 


\begin{tabular}{|c|c|c|c|}
\hline & (1) & $(2)$ & (3) \\
\hline Dependent Variable & $\begin{array}{l}\text { Nonabducted Mean } \\
\quad \text { (from Table 1) }\end{array}$ & $\begin{array}{l}\text { Marginal Impact } \\
\text { of Abduction }\end{array}$ & $\%$ Change \\
\hline Voted in 2005 & .40 & $\begin{array}{l}.110 \\
{[.036]^{* * *}}\end{array}$ & $27 \%$ \\
\hline Community mobilizer & .03 & $\begin{array}{l}.034 \\
{[.012]^{* * *}}\end{array}$ & $106 \%$ \\
\hline Political employment & .003 & $\begin{array}{l}.006 \\
{[.005]}\end{array}$ & $190 \%$ \\
\hline Any community group member & .41 & $\begin{array}{c}-.007 \\
{[.045]}\end{array}$ & $-2 \%$ \\
\hline Peace group member & .05 & {$[.043$} & $92 \%$ \\
\hline Water committee member & .02 & $\begin{array}{c}-.009 \\
{[.011]}\end{array}$ & $-43 \%$ \\
\hline Cultural group member & .15 & $\begin{array}{l}-.021 \\
{[.049]}\end{array}$ & $-14 \%$ \\
\hline Sporting group/team member & .13 & $\begin{array}{l}-.060 \\
{[.033]^{*}}\end{array}$ & $-44 \%$ \\
\hline Farmer's cooperative member & .10 & $\begin{array}{c}.002 \\
{[.015]}\end{array}$ & $2 \%$ \\
\hline School club/committee member & .05 & $\begin{array}{l}.024 \\
{[.022]}\end{array}$ & $49 \%$ \\
\hline Church or bible study group member & .18 & $\begin{array}{c}.032 \\
{[.049]}\end{array}$ & $18 \%$ \\
\hline Attends church & .79 & $\begin{array}{c}-.014 \\
{[.041]}\end{array}$ & $-2 \%$ \\
\hline Volunteer & .04 & $\begin{array}{c}.004 \\
{[.015]}\end{array}$ & $10 \%$ \\
\hline Disobeys elders & .06 & $\begin{array}{l}.035 \\
{[.023]}\end{array}$ & $63 \%$ \\
\hline Bottom quartile of prosocial distribution & .27 & $\begin{array}{c}-.075 \\
{[.046]}\end{array}$ & $-28 \%$ \\
\hline Physical fight & .07 & $\begin{array}{c}-.024 \\
{[.021]}\end{array}$ & $-35 \%$ \\
\hline Ever quarrelsome & .06 & $\begin{array}{l}.005 \\
{[.008]}\end{array}$ & $8 \%$ \\
\hline Ever threatens to hurt others & .01 & $\begin{array}{c}.019 \\
{[.012]}\end{array}$ & $168 \%$ \\
\hline \multicolumn{4}{|c|}{$\begin{array}{l}\text { Notes: Each item in Column } 2 \text { is the product of a separate regression. } \\
\text { Robust standard errors in brackets, clustered by sampling location. } \\
\text { †Calculated as the coefficient on an abduction dummy variable in a weighted probit regression of the } \\
\text { dependent variable on the abduction dummy, age (including the square and cube), location dummy variables, } \\
\text { and prewar household traits. The regression is weighted on inverse selection, sampling, and attrition } \\
\text { probabilities. } \\
{ }^{*} \text { Significant at } 10 \% \text {; }{ }^{* *} \text { significant at } 5 \% ; * * \text { significant at } 1 \% \text {. }\end{array}$} \\
\hline
\end{tabular}

nonparametric selection weights, and the attrition correction (results not displayed).

\section{Discussion}

First and foremost, the popular picture of former combatants-damaged, alienated, and potentially violent-finds little support in these data. Rather, former abductees are just as likely to belong to social groups as the nonabducted and just as unlikely to report antisocial behaviors.

Several qualitative studies echo these results. For instance, a psychosocial study of northern Ugandan youth by Annan, Brier, and Aryemo (2008) finds that abductees commonly reported problems with family or community immediately on return, but that such reintegration problems diminished rapidly with time. Families and communities were generally welcoming, and more than $95 \%$ of the abducted youth in the sample returned home. In their studies of Acholi cosmology and reconciliation processes, Baines (2005) and Harlacher et al. (2006) argue that such reintegration was facilitated by a cultural ethos of reconciliation and a public campaign for forgiveness and acceptance by public officials, religious leaders, and NGOs. Similarly high rates of community reconciliation and 
acceptance have also been reported in countries such as Sierra Leone (e.g., Wessells 2006; Williamson 2006).

Most surprising, the analysis suggests that abduction leads to a substantial increase in levels of political engagement. The survey's measures of political participation are admittedly limited in scope, confined to voting, community leadership, and political jobs, and hence, some caution is warranted. In each case, however, the impacts of abduction on political participation are relatively large. The increase in voting among abductees is comparable to the average effect of compulsory voting laws in a sample of 324 international elections (Blais and Dobrzynska 1998). Abduction's impact is also orders of magnitude greater than the average impacts of canvasing and other turnout efforts in U.S. elections (Gerber and Green 2000; Green and Gerber 2004). Unfortunately, comparable African benchmarks do not exist.

The evidence also suggests that abductees' community engagement is generally positive and civic in nature. Community mobilization is a productive role in the village, undertaken by the most confident and public-minded youth. Voting in the 2005 referendum was peaceful overall, and the measure received broad support, with $92 \%$ of national voters supporting the measure (IFES 2007). The survey did not track politically contentious outcomes, however, and so we cannot exclude the possibility that abductees are also more politically contentious or polarized.

We do observe some evidence of elevated aggression in abductees in the form of threats (although not in reports of fighting or asocial behavior). Selfreported threats are not significantly correlated with voting and community mobilization, however, suggesting the more aggressive youth are not the same as those that are politically active. The incidence of such hostility is also very small in absolute terms. Indeed, psychosocial studies in Uganda have emphasized the contrary: abducted youth tend to respond passively in response to harassment or aggression in order to avoid stigma, signal their peacefulness to the wider community, avoid painful memories of the war, and, in some cases, for fear of their own potential for aggression (Annan, Brier, and Aryemo 2008; Veale and Stavrou 2007).

The remainder of the article explores possible rationales for the relationship between abduction and political participation. Before doing so, however, it is worth asking whether the impacts we observe could be spurious-the result of unobserved selection effects rather than changes in behavior. Several plausible sources of bias exist. For instance, the impacts on political participation would be overstated if more politically active youth were more likely to join (or be targeted by) the LRA, or if the less clever, confident, or politically engaged abductees were more likely to be killed. Although such selection is unknowable, we can engage in a thought experiment, asking how influential such bias would have to be in order to account for the effects we observe. The Appendix describes the results of two forms of formal sensitivity analysis. One analysis, displayed in Figure 1, models unobserved selection into the LRA, and finds that even an unobserved factor as influential as our primary determinants of abduction-age and locationwould reduce but not eliminate the impact of abduction on voting, leaving the general conclusion intact. A second method estimates the degree of selective nonreturn from abduction that would be required to generate the impact we observe, and finds that rates of turnout among nonreturned abductees would have to be zero in order for the selection story to drive the impacts we observe. Such scenarios are extremely unlikely.

\section{UNPACKING THE CAUSAL MECHANISM}

Abduction by the LRA includes a multitude of war experiences. To unpack the mechanism linking abduction to participation, we can look for relationships between participation and war experiences among former abductees. Table 4 displays regressions of a subset of the participation and aggression indicators on war experiences, including violent acts, the log of months abducted, and indicators for whether the abductee carried his own firearm, held a leadership position, passed through a reception center, or later received NGO services.

Two caveats are in order. First, unlike abduction, war experiences may not be exogenous, meaning the estimates could be biased. War experiences, violence in particular, are also measured with error. Our indices of violence record incidence, not frequency, and so they systematically understate the number of acts ever experienced. Abductees may also not admit their most terrible experiences. Such systematic error would increase standard errors and bias the violence coefficient toward zero, in which case the Table 4 estimates should be considered a lower bound on the influence of violence on participation. ${ }^{11}$

\section{Results}

Abductees who witnessed the most acts of violence are the most likely to participate politically later in life. Each additional act of violence witnessed is associated with a 4.2 percentage point increase in the probability of voting and a 2.3 percentage point increase in the probability of being a community mobilizer, both significant at the $5 \%$ level at least (Columns 1 and 2). Are these effects large? The average abducted youth reports 1.8 more acts of violence witnessed than nonabducted youth, and so the coefficients in Table 4

\footnotetext{
${ }^{11}$ Even if the bias were in the opposite direction, measurement error is still unlikely to account for the correlation we observe. For systematic measurement error to alter the conclusions, it must be associated with both abduction and the outcome of interest, not simply abduction, and must be sufficiently large to change the conclusion. Measurement error can be seen as an omitted variable, and thus considered in the sensitivity analysis in Figure 1 . As with other omitted variables, the amount of measurement error needed to change the coefficient by an order of magnitude is implausibly large.
} 


\section{FIGURE 1. Impact of Relaxing the Assumption of Unconfoundedness}

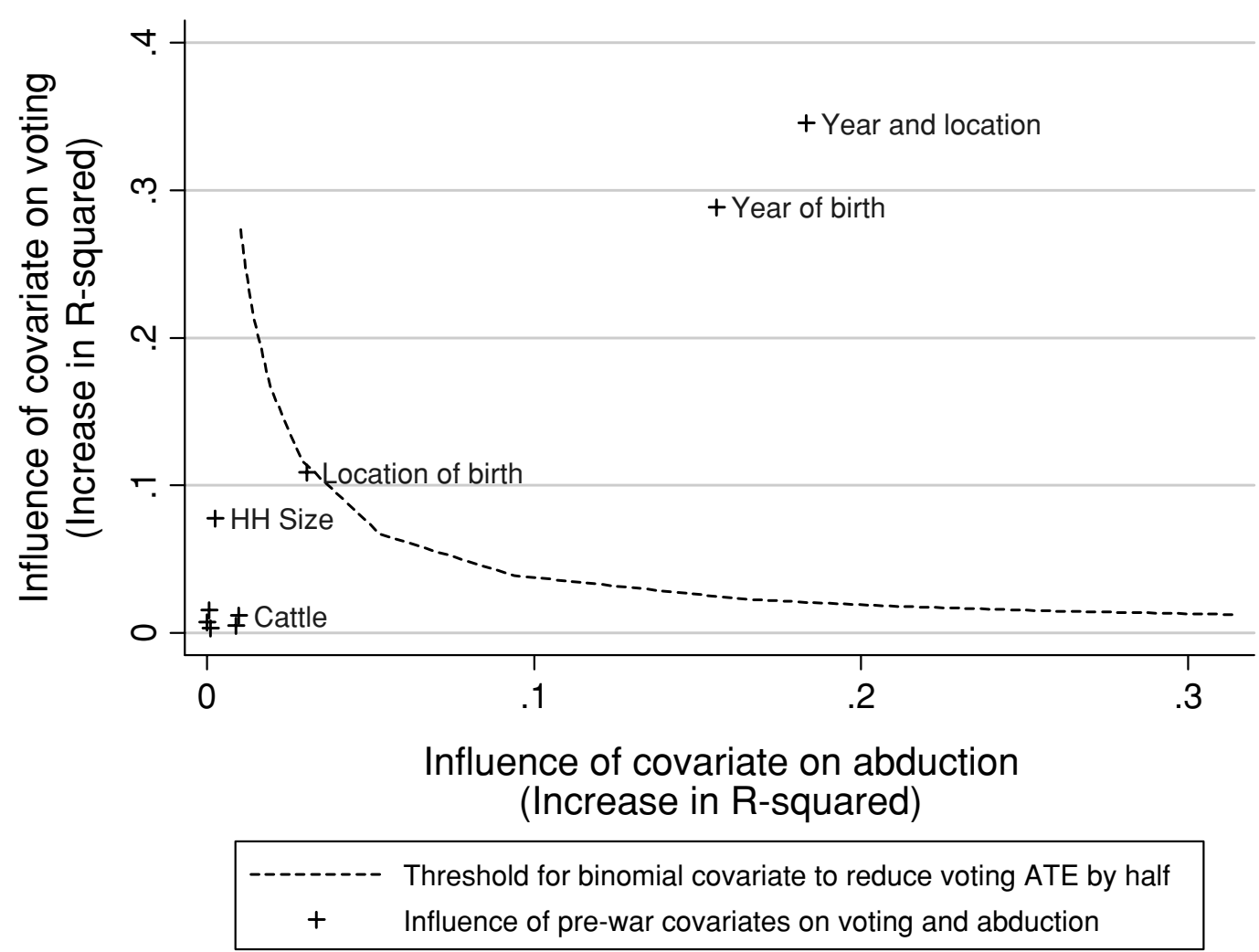

Notes: The figure presents the results of the sensitivity analysis following Imbens (2003). Each + represents a prewar covariate, plotted according to its additional explanatory power for treatment assignment (on the horizontal axis) and its explanatory power for the outcome (vertical axis), which in this case is educational attainment. In essence, each axis measures the increase (or decrease) in the $R^{2}$ statistic from adding that covariate to the regression in question. The downward sloping curve represents the locus of points at which any independent binomial covariate (observed or unobserved) would have sufficient association with both treatment and outcomes to halve the ATE.

imply that violence witnessed is associated with a 7 percentage point increase in voting among abductees (67\% of abduction's total impact, as seen in Table 3 ) and a 4 percentage point increase in community mobilization (119\% of abduction's impact).

We also see a somewhat significant relationship between violence witnessed and community group membership (Column 3); each act of violence witnessed is associated with a 5.2 percentage point increase in group membership, significant at the $10 \%$ level. We do not, however, see a consistently significant relationship between violence witnessed and aggression, whether measured by physical fights, quarrels, or having ever threatened others.

Abductees who experienced more family violence are also more likely to be a community mobilizer. Although the coefficient, .026, is large in absolute terms, abductees and nonabductees report nearly identical levels of family violence (Table 1). Thus, such acts cannot be responsible for the impact of abduction on political participation we observe in Table 3.

Looking at other war experiences, none are as robustly and as consistently related to our measures of political participation as is violence witnessed. Neither the violence received, violence perpetrated, nor abduction length measures consistently with political participation, community group membership, or aggression.

Having carried a firearm is not significantly related to participation. Having held a leadership position in the LRA, however, is associated with a large, 26.4 percentage point decrease in the probability of voting. There is no substantive relationship between leadership and the other measures of participation and aggression, however. Finally, former abductees who passed through a reception center are somewhat more likely to vote but not become community leaders.

\section{Discussion}

The analysis suggests that violence, especially violence witnessed, is the main mechanism by which abduction impacts participation: acts witnessed are strongly and significantly associated with voting and mobilization, acts witnessed differ between abducted and nonabducted youth, and they can account for the bulk of the impact of abduction on voting and mobilization. 


\begin{tabular}{|c|c|c|c|c|c|c|}
\hline & (1) & (2) & (3) & (4) & (5) & (6) \\
\hline & \multicolumn{3}{|c|}{ Participation } & \multicolumn{3}{|c|}{ Aggression } \\
\hline & $\begin{array}{l}\text { Voted } \\
\text { in } 2005\end{array}$ & $\begin{array}{l}\text { Community } \\
\text { Mobilizer }\end{array}$ & $\begin{array}{l}\text { Any Com- } \\
\text { munity } \\
\text { Group }\end{array}$ & $\begin{array}{l}\text { Physical } \\
\text { Fight }\end{array}$ & $\begin{array}{c}\text { Ever } \\
\text { Quarrelsome }\end{array}$ & $\begin{array}{l}\text { Ever } \\
\text { Threatens to } \\
\text { Hurt Others }\end{array}$ \\
\hline Violent acts witnessed & $\begin{array}{l}.042 \\
{[.019]^{* *}}\end{array}$ & $\begin{array}{l}.023 \\
{[.007]^{* * *}}\end{array}$ & $\begin{array}{l}.052 \\
{[.026]^{*}}\end{array}$ & $\begin{array}{l}.001 \\
{[.008]}\end{array}$ & $\begin{array}{l}.001 \\
{[.007]}\end{array}$ & $\begin{array}{l}.015 \\
{[.009]}\end{array}$ \\
\hline Violent acts on family & $\begin{array}{l}-.001 \\
{[.024]}\end{array}$ & $\begin{array}{l}.026 \\
{[.006]^{* * *}}\end{array}$ & $\begin{array}{l}.007 \\
{[.031]}\end{array}$ & $\begin{array}{l}-.017 \\
{[.009]^{*}}\end{array}$ & $\begin{array}{l}-.002 \\
{[.005]}\end{array}$ & $\begin{array}{c}-.006 \\
{[.007]}\end{array}$ \\
\hline Violent acts received & $\begin{array}{l}.014 \\
{[.019]}\end{array}$ & -.007 & $\begin{array}{r}-.022 \\
{[.021]}\end{array}$ & $\begin{array}{l}.007 \\
{[.012]}\end{array}$ & ${ }^{0}[.004]$ & $\begin{array}{l}-.002 \\
{[.006]}\end{array}$ \\
\hline Violent acts perpetrated & $\begin{array}{l}.014 \\
{[.022]}\end{array}$ & $\begin{array}{l}-.003 \\
{[.007]}\end{array}$ & $\begin{array}{l}.010 \\
{[.020]}\end{array}$ & $\begin{array}{l}.014 \\
{[.007]^{* *}}\end{array}$ & $\begin{array}{l}.004 \\
{[.005]}\end{array}$ & $\begin{array}{l}-.002 \\
{[.004]}\end{array}$ \\
\hline In (Months abducted) & $\begin{array}{l}-.033 \\
{[.018]^{*}}\end{array}$ & $\begin{array}{l}-.011 \\
{[.009]}\end{array}$ & $\begin{array}{l}-.032 \\
{[.019]}\end{array}$ & $\begin{array}{l}-.005 \\
{[.010]}\end{array}$ & $\begin{array}{l}-.015 \\
{[.005]^{* * *}}\end{array}$ & $\begin{array}{l}-.002 \\
{[.005]}\end{array}$ \\
\hline Carried own firearm & $\begin{array}{l}.002 \\
{[.071]}\end{array}$ & $\begin{array}{l}-.029 \\
{[.031]}\end{array}$ & $\begin{array}{l}-.014 \\
{[.068]}\end{array}$ & $\begin{array}{l}-.036 \\
{[.027]}\end{array}$ & $\begin{array}{l}.072 \\
{[.029]^{* *}}\end{array}$ & $\begin{array}{l}.006 \\
{[.036]}\end{array}$ \\
\hline Leadership position & $\begin{array}{l}-.264 \\
{[.080]^{* * *}}\end{array}$ & $\begin{array}{l}.000 \\
{[.065]}\end{array}$ & $\begin{array}{l}-.040 \\
{[.093]}\end{array}$ & $\begin{array}{l}-.013 \\
{[.052]}\end{array}$ & $\begin{array}{l}-.012 \\
{[.017]}\end{array}$ & $\begin{array}{l}.106 \\
{[.071]}\end{array}$ \\
\hline \multirow[t]{2}{*}{$\begin{array}{l}\text { Passed through } \\
\text { reception center }\end{array}$} & .157 & -.024 & -.068 & .062 & .046 & -.024 \\
\hline & {$[.083]^{*}$} & {$[.032]$} & {$[.066]$} & {$[.042]$} & {$[.025]^{*}$} & {$[.047]$} \\
\hline Received services & $\begin{array}{c}-.119 \\
{[.079]}\end{array}$ & $\begin{array}{l}.035 \\
{[.042]}\end{array}$ & $\begin{array}{l}.098 \\
{[.080]}\end{array}$ & $\begin{array}{c}-.020 \\
{[.021]}\end{array}$ & $\begin{array}{c}-.029 \\
{[.016]^{*}}\end{array}$ & $\begin{array}{l}.017 \\
{[.020]}\end{array}$ \\
\hline \multicolumn{5}{|l|}{ Controls not displayed: } & 458 & 458 \\
\hline Age (three orders) & $x$ & $x$ & $x$ & $x$ & $x$ & $x$ \\
\hline $\begin{array}{l}\text { Location of birth } \\
\text { dummies }\end{array}$ & $\hat{x}$ & $\hat{x}$ & $\hat{x}$ & $x$ & $x$ & \\
\hline Household traits in 1996 & $x$ & $x$ & $x$ & $x$ & $x$ & $x$ \\
\hline
\end{tabular}

Violence against family is a key determinant ofparticipation among abductees, but it cannot explain the gap with nonabductees.

This pattern holds if we examine the relationship between abduction and violence among all youth, including the nonabducted. In a regression of voting and community mobilization on violence, abduction, and abduction length (Table 5), a youth who witnessed an additional act of violence is 4.0 percentage points more likely to vote and 1.4 percentage points more likely to be a community mobilizer. Youth whose family experiences an additional act of violence are also 1.9 percentage points more likely to be a community mobilizer. As with abductees alone, youth who receive or perpetrate greater violence do not appear to participate any more or less. Violence is not significantly associated with any of our measures of aggression in the full sample.

The remainder of the article explores the possible explanations between violence witnessed and political participation.

\section{ALTERNATIVE EXPLANATIONS AND MECHANISMS}

What theories of political behavior could explain such patterns? Although it is difficult to prove a particular mechanism or channel is at work with the evidence at hand, we can begin by eliminating some of the plausible alternatives.

\section{Mobilization by Elites or NGOs}

Mobilization of youth by elites, parties, and NGOs is common in Africa, and the mobilization of excombatants has been documented in instances such as the 2007 election in Sierra Leone (Christensen and Utas 2008). Such groups can mobilize participation using social pressure or material goods (e.g., Green and Gerber 2004; Shachar and Nalebuff 1999; Uhlaner 1989).

Mobilization is an unlikely account of abductee participation in Uganda, however. First, no voter 
Vol. 103, No. 2

\begin{tabular}{|c|c|c|c|c|c|c|}
\hline & (1) & (2) & (3) & (4) & $(5)$ & (6) \\
\hline & \multicolumn{3}{|c|}{ Participation } & \multicolumn{3}{|c|}{ Aggression } \\
\hline & Voted in 2005 & $\begin{array}{l}\text { Community } \\
\text { Mobilizer }\end{array}$ & $\begin{array}{l}\text { Any } \\
\text { Community } \\
\text { Group }\end{array}$ & Physical Fight & $\begin{array}{c}\text { Ever } \\
\text { Quarrelsome }\end{array}$ & $\begin{array}{c}\text { Ever } \\
\text { Threatens } \\
\text { to Hurt } \\
\text { Others }\end{array}$ \\
\hline Violent acts witnessed & $\begin{array}{l}.040 \\
{[.023]^{*}}\end{array}$ & $\begin{array}{l}.014 \\
{[.004]^{* * *}}\end{array}$ & $\begin{array}{l}.057 \\
{[.022]^{* *}}\end{array}$ & $\begin{array}{c}-.007 \\
{[.008]}\end{array}$ & $\begin{array}{l}-.004 \\
{[.005]}\end{array}$ & $\begin{array}{c}.008 \\
{[.005]}\end{array}$ \\
\hline Violent acts on family & $\begin{array}{l}-.013 \\
{[.014]}\end{array}$ & $\begin{array}{l}.019 \\
{[.004]^{* * *}}\end{array}$ & $\begin{array}{c}.009 \\
{[.020]}\end{array}$ & $\begin{array}{c}-.005 \\
{[.007]}\end{array}$ & $\begin{array}{c}-.003 \\
{[.005]}\end{array}$ & $\begin{array}{r}-.002 \\
{[.004]}\end{array}$ \\
\hline Violent acts received & $\begin{array}{c}.024 \\
{[.023]}\end{array}$ & $\begin{array}{c}-.009 \\
{[.008]}\end{array}$ & $\begin{array}{l}-.047 \\
{[.015]^{* * *}}\end{array}$ & $\begin{array}{l}.004 \\
{[.010]}\end{array}$ & $\begin{array}{c}.008 \\
{[.006]}\end{array}$ & $\begin{array}{c}-.003 \\
{[.004]}\end{array}$ \\
\hline Violent acts perpetrated & $\begin{array}{c}-.006 \\
{[.025]}\end{array}$ & $\begin{array}{c}-.002 \\
{[.005]}\end{array}$ & $\begin{array}{c}.011 \\
{[.021]}\end{array}$ & $\begin{array}{l}.013 \\
{[.007]^{*}}\end{array}$ & $\begin{array}{c}.004 \\
{[.004]}\end{array}$ & $\begin{array}{c}.000 \\
.000 \\
{[.003]}\end{array}$ \\
\hline Ever abducted & $\begin{array}{c}.030 \\
{[.052]}\end{array}$ & $\begin{array}{c}.033 \\
{[.015]^{* *}}\end{array}$ & $\begin{array}{c}.026 \\
{[.062]}\end{array}$ & $\begin{array}{c}-.052 \\
{[.034]}\end{array}$ & $\begin{array}{c}-.010] \\
-.010 \\
{[.025]}\end{array}$ & $\begin{array}{l}.000 \\
.015 \\
{[.013]}\end{array}$ \\
\hline Months abducted & $\begin{array}{l}-.004 \\
{[.002]^{* *}}\end{array}$ & $\begin{array}{c}-.001 \\
{[.001]}\end{array}$ & $\begin{array}{l}-.005 \\
{[.002]^{* * *}}\end{array}$ & $\begin{array}{l}.000 \\
{[.001]}\end{array}$ & $\begin{array}{l}.000 \\
{[.000]}\end{array}$ & $\begin{array}{c}.000 \\
{[.000]}\end{array}$ \\
\hline $\begin{array}{l}\text { Observations } \\
\text { Controls not displaved. }\end{array}$ & 531 & 737 & 737 & 737 & 737 & 737 \\
\hline Age (three orders) & $x$ & $x$ & $x$ & $x$ & $x$ & $x$ \\
\hline $\begin{array}{l}\text { Location of birth } \\
\text { dummies }\end{array}$ & $x$ & $x$ & $x$ & $x$ & $x$ & $x$ \\
\hline $\begin{array}{l}\text { Household traits in } \\
1996\end{array}$ & $x$ & $x$ & $x$ & $x$ & $x$ & $x$ \\
\hline
\end{tabular}

Notes: Robust standard errors in brackets, clustered by sampling location.

*Significant at $10 \%$; ** significant at $5 \%$; ${ }^{* * *}$ significant at $1 \%$.

mobilization efforts were observed by the author, local research assistants, or the community leaders interviewed. Indeed, at the time of the referendum, opposition parties were not yet allowed to organize, and turnout efforts are also outlawed on voting day. Second, community mobilizer elections are held outside the normal political cycle and are unrelated to party affiliation. Community members typically nominate several candidates, followed by a vote. None of the leaders interviewed could recall interference from political elites or discussion of political affiliations during these informal elections.

Third, the main indicators of interaction with NGOs-having passed through a reception center or received NGO services-are not strongly correlated with voting and community participation (Table 4). Passing through a reception center is associated with higher rates of voting (significant at only the $10 \%$ level), but the result is quite fragile to the specification employed (unlike our other results), and we were more concerned that NGO interaction would lead to community leadership positions rather than voter mobilization (of which there was none). If NGOs mobilized former abductees, they did not do so using their registries.

Finally, participation is associated with a relatively unobservable trait-violence witnessed-and not with a more easily observed marker of abduction, such as abduction itself or length of abduction. It is difficult to believe that youth were mobilized on the basis of such a hidden trait.

\section{Differential Costs}

Simple rational theories of participation suggest that it is decreasing in shoe leather and opportunity costs (Feddersen 2004; Riker and Ordeshook 1968). If these costs are lower among abductees, or the recipients of violence, it might account for the higher participation we observe. Proxies for higher shoe leather costs include indicators for not living in one's district of origin-for instance, having Migrated to a town or Migrated out of district. Bad health could also impede participation, measured using an Injury indicator and an indicator for being in the Top quartile of emotional distress proxy. Finally, opportunity cost is proxied by an Asset index, Days employed, and Gross earnings.

Logically, any factor responsible for the patterns we observe must meet three conditions: (1) it must differ between abducted and nonabducted youth, (2) it must be correlated with voting and mobilization, and (3) it should be associated with violence witnessed. Table 6 assesses the explanatory power of each proxy, calculating the difference between abductees and nonabductees and the correlation with three participation variables. Only one proxy, serious injuries, 
TABLE 6. Relative Explanatory Power of the Correlates of Participation

\begin{tabular}{|c|c|c|c|c|c|}
\hline & (1) & (2) & (3) & (4) & (5) \\
\hline & \multirow{2}{*}{$\begin{array}{c}\text { Impact of } \\
\text { Abduction } \\
\text { (ATE) }\end{array}$} & \multicolumn{2}{|c|}{$\begin{array}{l}\text { Voted in } 2005 \\
\text { Referendum }\end{array}$} & \multicolumn{2}{|c|}{ Community Mobilizer } \\
\hline & & Correlation & $\%$ of $\mathrm{ATE}^{\ddagger}$ & Correlation & $\%$ of $\mathrm{ATE}^{\ddagger}$ \\
\hline Currently lives in town & $\begin{array}{c}-.033 \\
{[.038]}\end{array}$ & $\begin{array}{c}.014 \\
{[.050]}\end{array}$ & $0 \%$ & $\begin{array}{l}-.048 \\
{[.023]^{* *}}\end{array}$ & $5 \%$ \\
\hline Currently lives outside home district & $\begin{array}{l}.005 \\
{[.026]}\end{array}$ & $\begin{array}{l}-.176 \\
{[.085]^{* *}}\end{array}$ & $-1 \%$ & $\begin{array}{c}.040 \\
{[.033]}\end{array}$ & $1 \%$ \\
\hline Serious injury & $\begin{array}{c}.093 \\
{[.022]^{* * *}}\end{array}$ & $\begin{array}{c}-.037 \\
{[.039]}\end{array}$ & $-3 \%$ & $\begin{array}{c}-.042 \\
{[.021]^{*}}\end{array}$ & $-11 \%$ \\
\hline Top quartile of emotional distress & $\begin{array}{l}.102 \\
{[.042]^{* *}}\end{array}$ & $\begin{array}{c}-.034 \\
{[.056]}\end{array}$ & $-3 \%$ & $\begin{array}{c}.015 \\
{[.015]}\end{array}$ & $5 \%$ \\
\hline Asset index & $\begin{array}{l}-.279 \\
{[.064]^{* * *}}\end{array}$ & $\begin{array}{c}-.001 \\
{[.037]}\end{array}$ & $0 \%$ & $\begin{array}{c}-.002 \\
{[.010]}\end{array}$ & $2 \%$ \\
\hline Days employed in past four weeks & $\begin{array}{l}1.24 \\
{[.791]}\end{array}$ & $\begin{array}{c}.003 \\
{[.003]}\end{array}$ & $3 \%$ & $\begin{array}{c}.002 \\
{[.001]^{* *}}\end{array}$ & $7 \%$ \\
\hline Gross cash earnings in past 4 weeks (USD) & $\begin{array}{r}-5891 \\
{[5689]}\end{array}$ & $\begin{array}{l}.000 \\
{[.000]^{* *}}\end{array}$ & $0 \%$ & $\begin{array}{c}.000 \\
{[.000]}\end{array}$ & $0 \%$ \\
\hline Volunteer & $\begin{array}{c}.012 \\
{[.012]}\end{array}$ & $\begin{array}{c}.212 \\
{[.109]^{*}}\end{array}$ & $2 \%$ & $\begin{array}{c}.035 \\
{[.048]}\end{array}$ & $1 \%$ \\
\hline Bottom quartile of pro-social distribution & $\begin{array}{c}-.069 \\
{[.045]}\end{array}$ & $\begin{array}{c}-.002 \\
{[.058]}\end{array}$ & $0 \%$ & $\begin{array}{c}-.007 \\
{[.032]}\end{array}$ & $1 \%$ \\
\hline Index of 17 forms of social support & $\begin{array}{c}-.147 \\
{[.150]}\end{array}$ & $\begin{array}{c}.001 \\
{[.011]}\end{array}$ & $0 \%$ & $\begin{array}{c}.003 \\
{[.003]}\end{array}$ & $-1 \%$ \\
\hline Indicator for functional literacy & $\begin{array}{l}-.121 \\
{[.038]^{* * *}}\end{array}$ & $\begin{array}{c}.007 \\
{[.052]}\end{array}$ & $-1 \%$ & $\begin{array}{c}-.012 \\
{[.033]}\end{array}$ & $4 \%$ \\
\hline Radio ownership & $\begin{array}{c}-.015 \\
{[.032]}\end{array}$ & $\begin{array}{c}-.053 \\
{[.062]}\end{array}$ & $1 \%$ & $\begin{array}{c}-.010 \\
{[.029]}\end{array}$ & $0 \%$ \\
\hline Educational attainment in years & ${ }^{-.702}$ & $\begin{array}{c}-.002 \\
{[.009]}\end{array}$ & $1 \%$ & $\begin{array}{c}.000 \\
{[.003]}\end{array}$ & $0 \%$ \\
\hline $\begin{array}{l}\text { Observations } \\
\text { Additional controls (not displayed) }\end{array}$ & 741 & 533 & & 741 & \\
\hline Age (three orders) & $\times$ & $x$ & & $\times$ & \\
\hline Location of birth dummies & $x$ & $\times$ & & $\times$ & \\
\hline Household traits in 1996 & $\times$ & $x$ & & $\times$ & \\
\hline $\begin{array}{l}\text { Notes: Robust standard errors in brackets, cluster } \\
\text { * Significant at } 10 \% \text {; }{ }^{* *} \text { significant at } 5 \% \text {; } * * * \text { signific } \\
\text { Figures in bold represent correlates that exhibit } \\
\text { statistically significant relationship with the measur } \\
\dagger \text { Each item in Column } 1 \text { is a separate regression. } \\
\text { variable in an ordinary least squares regression o } \\
\text { dummies, age/location interactions, and pretreatm } \\
\text { sampling probabilities and inverse attrition probabi } \\
\ddagger \text { Calculated as the ATE in Column } 1 \text { multiplied by }\end{array}$ & $\begin{array}{l}\text { ed by sampling } \\
\text { ant at } 1 \% \text {. } \\
\text { a statistically } \\
\text { re of participati } \\
\text {. Each ATE is } \\
\text { f the dependen } \\
\text { ent individual a } \\
\text { ilities. } \\
\text { the coefficient i }\end{array}$ & $\begin{array}{l}\text { location. } \\
\text { significant AT } \\
\text { ion (either Colc } \\
\text { calculated as } \\
\text { nt variable on a } \\
\text { and household } \\
\text { in Column 2, d }\end{array}$ & $\begin{array}{l}\text { E (at the } 5 \% \\
\text { umns } 2 \text { or } 4 \text { ). } \\
\text { the coefficien } \\
\text { abduction an } \\
\text { l characteristi } \\
\text { livided by the }\end{array}$ & $\begin{array}{l}\text { level) in Colu } \\
\text { th on an abduc } \\
\text { d controls (age } \\
\text { s). Weights in } \\
\text { relevant ATE ir }\end{array}$ & $\begin{array}{l}\text { umn } 1 \text { and a } \\
\text { tion indicator } \\
\text { and location } \\
\text { clude inverse } \\
\text { in Table } 3 .\end{array}$ \\
\hline
\end{tabular}

meets the criteria, albeit the sign is in the "wrong" direction: abductees are more likely to be injured, but injured youth are less likely to be mobilizers. Hence, abductees' heightened leadership comes despite their costly injuries, not because of them. None of the other proxies for shoe leather and opportunity costs appear influential.

\section{Altered Social Preferences}

Other participation theorists have proposed that individuals have altruistic preferences and take into ac- count the benefit of their actions to others (e.g., Edlin, Gelman, and Kaplan 2007; Feddersen and Sandroni 2002; Harsanyi 1977, 1992). Military conditioning, or violent or near-death experiences, could in principle alter such preferences and increase participation among abductees. If so, we should observe that individuals who participate politically also make other social contributions, such as public goods management (e.g., school and water groups) or being a volunteer. We might also expect to observe higher levels of prosocial behavior, such as respectfulness and cooperation. The survey measures both Prosocial behavior and an Index 
of social support received. According to the estimates in Table 6, abductees do not exhibit greater social contributions or group participation, and prosocial behavior and social support are actually lower. We see no evidence of a general shifts in altruism.

\section{Augmented Information}

Finally, a set of theories proposes that informed voters are more likely to participate (e.g., Feddersen and Pesendorfer 1999). Information is proxied by indicators for Functional literacy, Radio ownership, and Educational attainment, all included in Table 6. Abductees, however, are considerably less (not more) likely to be literate, educated, or own a radio. Moreover, none of these traits are closely associated with voting, suggesting that formal education and information are not the channel of impact. Naturally, this analysis does not preclude the influence of other types of information or experience. War and abduction are undoubtedly learning experiences that may transform the perceived costs and benefits of participation. But the simple educationvoting correlation seen in the United States is not replicated here.

\section{WHAT THE ABDUCTEES SAY}

To better understand the role of abduction and violence in political participation, we turn to interviews with former abductees, leaders, social workers, and political party operators. As discussed previously, the qualitative evidence is limited in scope. Even so, several patterns emerged from the semistructured interviews.

First, several abducted youth described, after return, a sense of power over their lives and events. Abductees commonly witnessed terrible acts and even came close to death themselves. One youth emphasized that after such experiences, he felt he could face anything in civilian life. Another spoke of "making up for lost time", and a third spoke of finding purpose after the violence-a sense he was "chosen". 12

The decision to escape from the LRA in particular was framed in language of self-determination and control. Several youth described a turning point where the "scales fell from their eyes", whereupon they realized that the propaganda fed to them by the rebel leadership-the righteousness of violence, or the seizure of the government-was false..$^{13}$ In some cases, this realization was associated with witnessing or experiencing a terrible and seemingly senseless act of violence. In a crucial act of self-determination, the youth took back control of their lives and decided to run away.

Interviews with elders and other community leaders yielded similar sentiments. According to a reception center social worker, who also worked as an election poll supervisor during the previous two elections, formerly abducted youth "feel like they can take control

\footnotetext{
12 Author's interview with Abductee 4 (17 June 2007), Abductee 7 (19 June 2007), and Abductee 19 (22 June 2007).

13 Author's interview with Abductee 7 (19 June 2007), Abductee 10 (20 June 2007), and Abductee 15 (21 June 2007).
}

of their lives," and "are subjected to hardship where. . they mature very fast." 14 Asked their opinion of formerly abducted youth, elders and leaders from several different villages explained that abduction (and violence in particular) is an experience that "matured" abducted youth and made them "more serious." 15 These same terms are ones commonly used in Acholi culture to describe the difference between a boy and a man. The experience of violence was thus associated with local processes of maturation.

Not all abducted youth expressed an increased sense of control. The majority of youth (abducted or not) took pains to highlight their idleness, helplessness, and despair. At the time of the field work, respondents (like the entire district rural population) had been displaced from their homes and livelihoods for at least four years. Few places on Earth are poorer or more desperate. Abductee accounts of marginal gains in control and outlook must be considered against this backdrop of misery. ${ }^{16}$

A second rationale for abductees' leadership is their comfort with public speaking and airing their opinion to others. Acholi leaders commonly attributed their own role in the community, and their nomination to elected positions, to such confidence and skills. Likewise, one elder suggested that war trauma gave abducted youth "courage to speak their minds," whereas a poll and social worker emphasized that former abductees "comfortably speak their views in a group of people or a crowd." 17 The informants attributed these behaviors to the training and experience in the LRA, as well as the confidence borne of experience as a fighter.

Such accounts suggest a change in both perspective and ability. That is, in addition to a change in selfregard, abductees may have acquired leadership skills in the bush, and so they lead at home because they are more able (rather than simply more optimistic or confident). The evidence for skills and experience, however, is weak. First, we do not observe a strong correlation between political participation and leadership roles in the LRA. If anything, leadership is associated with less participation, at least in the form of voter turnout (Table 4). Second, there is little systematic relationship between abduction length (another reasonable proxy for experience) and political engagement. Third, if skills are the relevant channel, the link to violence witnessed is not clear. A change in personal goals, perspective, or self-regard, although impossible to prove, is more consistent with the patterns we observe.

\footnotetext{
14 Author's interview with Poll worker 1 (20 June 2007).

15 Author's interview with Leader 2 (17 June 2007), Leader 4 (19 June 2007), and Leader 5 (20 June 2007).

16 Also, although abduction is associated with greater control over the present and future, an absence of past control is associated with resilience. Abductees commonly and successfully coped with traumatic memories by attributing their ordeals to "God's will", suggesting that they were not responsible for their acts. An absence of self-blame was strongly associated with psychological resilience, as was an ability to "forget" bad experiences and focus on the future (Annan et al. 2008).

17 Author's interview with Leader 1 (17 June 2007), and Poll worker 2 (22 June 2007).
} 


\section{Theoretical Interpretations}

There are at least three plausible interpretations of the interview accounts. The first draws on a body of psychological research the potential for growth after traumatic experiences. Traditionally, psychologists have focused on the damaging effects of violent trauma (as well as the widespread resilience to such experiences).$^{18}$ Yet, in case after case of traumatic experience-including fatal diseases, rape, assault, house fires, plane crashes, war violence, and loss of a loved one-reports of "posttraumatic growth" experiences consistently outnumber reports of psychiatric disorders (Tedeschi and Calhoun 2004).

Indeed, a growing body of case evidence suggests that there are five major domains of personal growth after traumatic experiences: a greater appreciation of life and changed sense of priorities; warmer, more intimate relationships with others; a greater sense of personal strength; recognition of new possibilities or paths for one's life; and spiritual development (e.g., Emmons, Colby, and Kaiser 1998; Haidt 2006; Nolen-Hoeksema and Davis 2002; Tedeschi and Calhoun 1996).

A small number of these studies look specifically at the victims of war violence, finding self-reported levels of personal growth among Yugoslav refugees (Powell et al. 2003), U.S. World War II veterans (Elder and Clipp 1989), U.S. prisoners of war in Vietnam (Sledge, Boydstun, and Rabe 1980), and Israeli adolescents exposed to terror incidents (Laufer and Solomon 2006). In most cases, the degree of growth is positively associated with the harshness of the violence. These studies argue that surviving a traumatic event unleashes several processes: it reveals hidden abilities and changes one's self-concept, it initiates a personal evaluation and shifts goals and priorities, and it shatters previous belief systems and leads to a struggle to make meaning from the experience.

These studies do not, however, distinguish between different forms of victimization-whether violence witnessed, received, or on the family. Accounts of posttraumatic growth also have several weaknesses: they are typically self-reported, difficult to verify, and must be taken at face value (Tennen and Affleck 1998). Comparison groups are also seldom employed. The parallel to abductees' political accounts is nonetheless striking.

A second possible interpretation come from " $\mathrm{ex}$ pressive" theories of participation, where individuals are presumed to value the act of political expression itself (Downs 1957; Fiorina 1976; Riker and Ordeshook 1968). The origin of such preferences, and the reasons for variation across people and time, are poorly understood. If posttraumatic growth theorists are correct, however, the reordering of personal goals and priorities after witnessing a traumatic event could alter one's information set, expectations, or tastes for participation in proportion to the trauma received. Like theories

\footnotetext{
${ }^{18}$ Studies commonly find that only a minority of victims develop long-term emotional distress and other disorders (e.g., Elder and Clipp 1989; King et al. 1998; Luthar, Cicchetti, and Becker 2000; Masten 2001)
}

of posttraumatic growth, however, expressive preferences (and changes) are difficult to test or disprove. Also, the specific link to violence witnessed remains a puzzle.

Finally, traumatic events may not simply change perceptions, but actually provide concrete information and experience. Former abductees may be better informed of the costs of conflict than their peers. They have also traveled widely and met people of different countries and cultures. They have learned to fight and work as a group toward common goals, and have proven their mettle in escaping from the rebel group. Such experience may not only change the calculus of participation, but also the personal returns to collective action. Although the potential relationship between these abilities and violence received is not clear, we cannot dismiss the possibility of a link.

\section{CONCLUSION}

Survey evidence from Uganda suggests that the victims of violence are just as likely as their peers to participate socially and behave aggressively. They are considerably more likely, however, to vote and lead in their communities.

This link from violent trauma to increased participation has been observed elsewhere after war. Bellows and Miguel (2008) observe similar patterns in Sierra Leone: civilians whose household experienced a killing, maiming, or displacement are more likely to attend community meetings; more likely to join political groups; and more likely to vote than peers. Similarly, Shewfelt (2009) interviews households in postconflict Aceh, Indonesia, and finds a strong positive correlation between an index of 43 traumatic events and political participation (e.g., political party membership) and other social groups (e.g., cultural, recreational, religious, and service groups). Finally, Carmil and Breznitz (1990) survey Jewish Holocaust survivors alongside a control group of their Israeli peers and find that survivors support more centrist political parties and express a greater belief in God and in a better future. Thus, the link we observe in Uganda could be part of a more general phenomenon linking trauma to activation.

It is a link, however, that is difficult to decipher. Several obvious channels of impact, such as mobilization of the disaffected, find little support. Meanwhile, interviews with the youth yield narratives of newfound selfcontrol, confidence, and skills. Such accounts, although far from conclusive, nonetheless mesh with psychological theories of posttraumatic growth and political evidence on expressive voting. The evidence thus focuses attention on a relatively unexplored area of study: the psychological foundations of political engagement, the sources of interpersonal variation, and the effects of experience, particularly traumatic experiences, on political attitudes and participation.

Such traumatic experiences are tragically common. Violence is endemic in developing countries. Among excombatants, in particular, forced recruitment and 
the controlled use of violence is at least as common in fighting forces as the use of voluntary participation and rewards (Beber and Blattman 2008; Humphreys and Weinstein 2008; Weinstein 2007). The LRA, which is frequently mischaracterized as an irrational and barbaric rebel group, is far from unique in this regard. ${ }^{19}$ Hence, these findings may have (hopeful) implications for millions of fighters in dozens of wartorn countries, especially in Africa. To the extent that positive political engagement also springs from violence against civilians, many more millions may be affected in the same way.

There are important limits, however, on this article's results. First, the political outcomes measured in the survey are few in number, so we should take caution in generalizing the findings to political participation more broadly. The determinants of other forms of political engagement could differ. Second, the results arise from data on male Ugandan youth, and may not apply to females or older adults, or other regions. Even so, the similarity between the Ugandan results and those from refugees and victims of war violence in other countries suggests some degree of external validity. Generalization of the results awaits more data collection in more situations of violence and conflict.

Finally, a more important question remains unanswered: why in Uganda did violence lead to peaceful and productive rather than contentious participation? The answer is undoubtedly societally and institutionally specific. Several aspects of Ugandan institutions and culture may have led to the generally positive political engagement we see: a functioning, relatively democratic government at the national and local level, vigorous and open local political systems that are inclusive of youth, and a society that generally welcomed former abductees back into the community. In the absence of any of these conditions, posttraumatic participation may have been muted or even destructive. Studies of young excombatants in Sierra Leone and Liberia, for instance, are considerably less optimistic about youths' positive political engagement, and even find evidence of violent electoral participation (Bøås and Hatløy 2006; Christensen and Utas 2008; Utas 2003). There are few more important questions in politics about who works peacefully within the system, who turns to violence, and why.

Despite these caveats, this article's findings suggest some important general lessons. If nothing else, we have seen that the proclivity for participation varies among individuals, they are malleable, and they can be shaped in systematic and predictable ways. Violence and hardship may be particularly influential, and in an unexpected direction, a positive one. In this conclusion, we may have been preceded by Shakespeare: "Sweet are the uses of adversity," he wrote, "Which like the

\footnotetext{
19 Anthropologists and political scientists that study the LRA take a different view, finding the guerrilla force to be much more conventional and strategic in its use of violence and spirituality than is represented by the Ugandan government and Western media (e.g., see Allen and Vlassenroot 2008; Lamwaka 2002; Lucima 2002; Finnström 2008a, 2008b; Blattman and Annan 2008; Branch 2008; Mwenda 2008; Schomerus 2008; Titeca 2008).
}

toad, ugly and venomous/Wears yet a precious jewel in his head." 20

\section{APPENDIX: SENSITIVITY ANALYSIS}

This appendix explores the sensitivity of the impacts of abduction (estimated in Table 3 ) to violations of some of the fundamental identification conditions, and illustrates that only under extreme and unlikely circumstances could the results we observe be generated by unobserved selection into the armed group, or selective attrition.

First, we can employ a method of sensitivity analysis based on Imbens (2003) that explicitly models a degree of unobserved selection into the armed group. Figure 1 plots each of the observed prewar control variables on two axes: a vertical axis that indicates the increase in explained variation (i.e., the increase in the $R^{2}$ statistic) that comes from adding the control to a regression of voting on all other controls, and a horizontal axis that indicates the influence of each control in explaining variation in abduction. Influence in both is a prerequisite for inducing a selection effect. As expected, only the year and location of birth indicators substantially influence both abduction and voting.

We can also engage in a thought experiment: model a hypothetical unobserved variable $U$, and ask how influential it would need to be to reduce the impact on voting by a substantial amount. In essence, this $U$ represents any source of self-selection, or selection on the part of the LRA, which we fear may lead to bias in the result. The question is then how much bias, relative to the observed covariates, would be enough to change out conclusions?

The downward sloping curve in Figure 1 represents all the combinations of (a) correlation between $U$ and abduction, and (b) correlation between $U$ and voting, that would be sufficient to halve the observed impact of abduction on voting. ${ }^{21}$ The curve is therefore a threshold, beyond which our hypothetical $U$ is influential enough to significantly reduce our result (although, we should note, still leave the direction and general magnitude of the impact intact). Only our age and location indicators exceed the threshold, implying that our hypothetical unobservable would need to be as influential as the primary determinants of abduction just to halve the observed treatment effect.

Another form of sensitivity analysis allows us to consider the potential effects of selective attrition. One option would be to follow Manski (1990) or Lee (2005) and estimate nonparametric bounds on the impact of abduction. Doing so leaves the general conclusions relatively unchanged, however, because attrition levels are nearly identical in the two groups. It is attrition patterns that differ. In particular, the abducted are uniquely likely not to return from abduction (almost all of whom can be presumed perished), whereas the nonabducted are more likely to have otherwise died, or migrated, and remain unfound.

We can perform a second thought experiment to consider whether the treatment effects we observe could be accounted for by different forms of selective attrition. For instance, what if voter turnout among nonabductees $(40 \%)$ is the "true" level of turnout among all youth, observed or not? What degree of selective return from abduction would be required to lead us to erroneously observe $51 \%$ turnout among former abductees? The answer is none: rates of voter turnout

\footnotetext{
${ }^{20}$ As You Like It, II.i.12-14, quoted in Haidt (2006).

21 The unobservable in question is modeled as a binomial variable independent of all other covariates that is assumed to have a logistic conditional distribution with both voting and abduction.
} 
among unreturned abductees would have to be zero in order for there to be no difference in turnout between abducted and nonabducted youth. ${ }^{22}$ A hypothetical turnout of $25 \%$ among unreturned abductees, meanwhile, would be sufficient to halve the estimated impact of abduction on voting, from 11 percentage points to 5.5. Even under such extreme assumptions, the general direction, magnitude, and significance of the impacts would not change.

\section{REFERENCES}

Allen, Tim. 2005. "War and Justice in Northern Uganda: An Assessment of the International Criminal Court's Intervention." London: Crisis States Research Centre, Development Studies Institute, London School of Economics.

Allen, Tim, and Koen Vlassenroot. 2008. "Introduction." In The Lord's Resistance Army: War, Peace and Reconciliation in Northern Uganda, eds. Tim Allen and Koen Vlassenroot. London School of Economics and Political Science. Typescript.

Annan, Jeannie, Christopher Blattman, and Roger Horton. 2006. "The State of Youth and Youth Protection in Northern Uganda: Findings from the Survey of War Affected Youth." Kampala, Uganda: UNICEF.

Annan, Jeannie, Moriah Brier, and Filder Aryemo. 2008. "From 'Rebel' to 'Returnee': Daily Life and Reintegration for Youth in Northern Uganda." Yale University. Unpublished working paper.

Baines, Erin. 2005. "Restoring Relationships in Acholi-Land: Traditional Approaches to Justice and Reintegration." Vancouver, Canada: Liu Institute.

BBC. 2007. "Child Soldiers 'Are a Time Bomb'." BBC News, February 5.

Beber, Bernd, and Christopher Blattman. 2008. "The Industrial Organization of Rebellion: The Logic of Forced Labor and Child Soldiering." Yale University Unpublished working paper.

Behrend, Heike. 1999. Alice Lakwena \& Holy Spirits: War In Northern Uganda 1985-97. Columbus: Ohio University Press.

Bellows, John, and Edward Miguel. 2006. "War and Institutions: New Evidence from Sierra Leone." American Economic Association, Papers and Proceedings 96 (2): 394-9.

Bellows, John, and Edward Miguel. 2008. "War and Local Collective Action in Sierra Leone.” Berkeley: UC Berkeley.

Blais, André, and Agnieszka Dobrzynska. 1998. "Turnout in Electoral Democracies." European Journal of Political Research 33 (2): 239-62.

Blattman, Christopher, and Jeannie Annan. N.d. "The Consequences of Child Soldiering." Review of Economics and Statistics. Forthcoming.

Blattman, Christopher, and Jeannie Annan. 2008. "On the Nature and Causes of LRA Abduction: What the Abductees Say." In The Lord's Resistance Army: War, Peace and Reconciliation in Northern Uganda, eds. Tim Allen and Koen Vlassenroot. London School of Economics and Political Science. Typescript.

Blattman, Christopher, and Edward Miguel. N.d. "Civil War." Journal of Economic Literature. Forthcoming.

Bøås, Morten, and Anne Hatløy. 2006. "After the 'Storm': Economic Activities among Returning Youths. The Case of Voinjama." Norway: Fafo Report.

Branch, Adam. 2008. "Exploring the roots of LRA Violence: Political Crisis and Politicized Ethnicity in Acholiland." In The Lord's Resistance Army: War, Peace and Reconciliation in Northern Uganda, eds. Tim Allen and Koen Vlassenroot. London School of Economics and Political Science. Typescript.

Carmil, Devora, and Shlomo Breznitz. 1990. "Personal Trauma and World View-Are Extremely Stressful Experiences Related to Political Attitudes, Religious Beliefs, and Future Orientation?" Journal of Traumatic Stress 4 (3): 393-405.

\footnotetext{
22 To calculate this amount, we assume $40 \%$ turnout among all youth that died or are absentees, and calculate the impact of abduction for the full sample of youth in the 1996 sample assuming different levels of turnout among unreturned abductees. A rate of zero turnout is required to reduce the impact of abduction on voting to zero.
}

Christensen, Maya M., and Mats Utas. 2008. "Mercenaries of Democracy: the 'Politricks' of Remobilized Combatants in the 2007 General Elections, Sierra Leone." African Affairs (London) adn057.

Cohn, Irene, and Guy S. Goodwin-Gill. 1994. Child Soldiers: The Role of Children in Armed Conflict. Oxford: Institut HenryDunant, Oxford University Press.

Collier, Paul. 2007. The Bottom Billion. Oxford: Oxford University Press.

Collier, Paul, V. L. Elliot, Håvard Hegre, Anke Hoeffler, Marta Reynal-Querol, and Nicholas Sambanis. 2003. Breaking the Conflict Trap: Civil War and Development Policy. Washington, DC: World Bank and Oxford University Press.

Doom, R., and K. Vlassenroot. 1999. "Kony's Message: A New Koine? The Lord's Resistance Army in Northern Uganda." African Affairs 98 (390): 5.

Downs, Anthony. 1957. An Economic Theory of Democracy. New York: Harper and Row.

Editorial. 2006. "Armies of Children." New York Times, October 12. Edlin, Aaron, Andrew Gelman, and Noah Kaplan. 2007. "Voting as a Rational Choice: Why and How People Vote to Improve the Well-Being of Others." Rationality and Society 19 (3): 293 314.

Elder, Glen H., and Elizabeth Colerick Clipp. 1989. “Combat Experience and Emotional Health: Impairment and Resilience in Later Life.” Journal of Personality 57 (2): 311-41.

Emmons, Robert A., Patricia M. Colby, and Heather A. Kaiser. 1998. "When Losses Lead to Gains: Personal Goals and the Recovery of Meaning." In The Human Quest for Meaning: A Handbook of Psychological Research and Clinical Applications, eds. P. T. P. Wong and P. S. Fry. Mahwah, NJ: Lawrence Erlbaum Associates.

Feddersen, Timothy J. 2004. "Rational Choice Theory and the Paradox of Not Voting." Journal of Economic Perspectives 18 (1): 99 112.

Feddersen, Timothy J., and Wolfgang Pesendorfer. 1999. “Abstention in Elections with Asymmetric Information and Diverse Preferences." American Political Science Review 93 (2): 381-98.

Feddersen, Timothy J., and Alvaro Sandroni. 2002. "A Theory of Participation in Elections." American Economic Review 96 (4): 1271-82.

Finnström, Sverker. 2008a. "An African Hell of Colonial Imagination? The Lord's Resistance Army/Movement in Uganda, Another Story." In The Lord's Resistance Army: War, Peace and Reconciliation in Northern Uganda, eds. Tim Allen and Koen Vlassenroot. London School of Economics and Political Science. Typescript.

Finnström, Sverker. 2008b. Living With Bad Surroundings: War and Existential Uncertainty in Acholiland, Northern Uganda. Durham, NC: Duke University Press.

Fiorina, Morris P. 1976. "The Voting Decision: Instrumental and Expressive Aspects." Journal of Politics 38 (2): 390-413.

Fitzgerald, John, Peter Gottschalk, and Robert Moffitt. 1998. "An Analysis of Sample Attrition in Panel Data: The Michigan Panel Study of Income Dynamics." Journal of Human Resources 33 (2): 251-99.

Gerber, Alan S., and Don P. Green. 2000. "The Effects of Canvassing, Telephone Calls, and Direct Mail on Voter Turnout: A Field Experiment." American Political Science Review 94 (3): 653-63.

Government of Uganda. 2007. "National Peace, Recovery and Development Plan for Northern Uganda: 2006-2009." Kampala, Uganda: Government of Uganda.

Green, Donald P., and Alan S. Gerber. 2004. Get out the Vote! Washington, DC: Brookings Institution Press.

Haidt, Jonathan. 2006. The Happiness Hypothesis: Finding Modern Truth in Ancient Wisdom. New York: Basic Books.

Hamory, Joan, and Edward Miguel. 2006. "Attrition and Migration in the Kenya Life Panel Survey." Berkeley: UC Berkeley.

Harlacher, Thomas, Francis Xavier Okot, Caroline Aloyo Obonyo, Mychelle Balthazard, and Ronald Atkinson. 2006. Traditional Ways of Coping in Acholi: Cultural Provisions for Reconciliation and Healing from War. Kampala, Uganda: Intersoft Business Services Ltd.

Harsanyi, John. 1977. "Morality and the Theory of Rational Behavior." Social Research 44 (4): 623-56. 
Harsanyi, John. 1992. "Game and Decision Theoretic Models in Ethics." In The Handbook of Game Theory, Volume 1, ed. R. A. a. S. Hart. Amsterdam: Elsevier, North Holland.

Hirano, Keisuke, Guido W. Imbens, and Geert Ridder. 2003. "Efficient Estimation of Average Treatment Effects Using the Estimated Propensity Score." Econometrica 71 (4): 116189.

Honwana, Alcinda. 2005. Child Soldiers in Africa. Philadelphia: University of Pennsylvania Press.

Humphreys, Macartan, and Jeremy M. Weinstein. 2008. "Who Fights? The Determinants of Participation in Civil War." American Journal of Political Science 52 (2): 436-55.

IFES. IFES Election Guide 2007. www.electionguide.org/results. php?ID=969. (May 8, 2007)

Imbens, Guido W. 2003. "Sensitivity to Exogeneity Assumptions in Program Evaluation." American Economic Review 93 (2): 12632.

King, Lynda A., Daniel W. King, John A. Fairbank, Terence M. Keane, and Gary A. Adams. 1998. "Resilience-Recovery Factors in Post-Traumatic Stress Disorder among Female and Male Vietnam Veterans: Hardiness, Postwar Social Support, and Additional Stressful Life Events." Journal of Personality and Social Psychology 74 (2): 420-34.

Lamwaka, Caroline. 2002. "The Peace Process in Northern Uganda 1986-1990." In Protracted Conflict, Elusive Peace: Initiatives to End the Violence in Northern Uganda, ed. O. Lucima. London: Conciliation Resources and Kacoke Madit.

Laufer, Avital, and Zahava Solomon. 2006. "Posttraumatic Symptoms and Posttraumatic Growth Among Israeli Youth Exposed to Terror Incidents." Journal of Social and Clinical Psychology 25 (4): 429-47.

Lee, David S., 2005. "Training, Wages, and Sample Selection: Estimating Sharp Bounds on Treatment Effects." In NBER Working Paper \#11721. Cambridge: National Bureau of Economic Research.

Loughry, M., and C. MacMullin. 2002. "An Investigation into the Psychosocial Adjustment of Formerly Abducted Child Soldiers in Northern Uganda." Kampala, Uganda: The International Rescue Committee.

Lucima, Okelo, ed. 2002. "Protracted Conflict, Elusive Peace: Initiatives to End the Violence in Northern Uganda." Accord 11.

Luthar, S. S., D. D. Cicchetti, and B. B. Becker. 2000. "The Construct of Resilience: A Critical Evaluation and Guidelines for Future Work." Child Development 71 (3): 543-62.

Manski, Charles F. 1990. "Nonparametric Bounds on Treatment Effects." American Economic Review 80 (2): 319-23.

Masten, A. S. 2001. "Ordinary Magic: Resilience Processes in Development." American Psychologist 56 (3): 227-38.

Mwenda, Andrew. 2008. "Uganda's Politics of Foreign Aid and Violent Conflict: The Political Uses of the LRA Rebellion." In The Lord's Resistance Army: War, Peace and Reconciliation in Northern Uganda, eds. Tim Allen and Koen Vlassenroot. London School of Economics and Political Science. Typescript.

Nolen-Hoeksema, Susan, and Christopher G. Davis. 2002. "Positive Responses to Loss: Perceiving Benefits and Growth." In Handbook of Positive Psychology, eds. C. R. Snyder and S. J. Lopez. New York: Oxford University Press, 598-607.

Omara-Otunnu, Amii. 1994. Politics and the Military in Uganda, 1890-1985. London: Macmillan, in association with St. Antony's College, Oxford.

Pham, Phuong, Patrick Vinck, and Eric Stover. 2007. "Abducted: The Lord's Resistance Army and Forced Conscription in Northern Uganda." Human Rights Center, University of California, Berkeley; Payson Center for International Development, Tulane University.

Powell, Steve, Rita Rosner, Willi Butollo, Richard G. Tedeschi, and Lawrence G. Calhoun. 2003. "Posttraumatic Growth After War: A Study with Former Refugees and Displaced People in Sarajevo." Journal of Clinical Psychology 59 (1): 71-83.
Richards, Paul, Steven Archibald, Khadija Bah, and James Vincent. 2003. "Where Have All the Young People Gone? Transitioning ExCombatants Toward Community Reconstruction After the War in Sierra Leone." Unpublished report. London: School of Oriental and African Studies.

Riker, William H., and Peter C. Ordeshook. 1968. "A Theory of the Calculus of Voting." American Political Science Review 62 (1): $25-42$.

Rosenbaum, Paul R., and Donald B. Rubin. 1983. "Assessing Sensitivity to an Unobserved Binary Covariate in an Observational Study with Binary Outcome." Journal of the Royal Statistical Society. Series B (Methodological) 45 (2): 212-18.

Rubin, Donald B. 1978. "Bayesian Inference for Causal Effects: The Role of Randomization." Annals of Statistics 6 (1): 34-58.

Schomerus, Mareike. 2008. "Chasing the Kony Story." In The Lord's Resistance Army: War, Peace and Reconciliation in Northern Uganda, eds. Tim Allen and Koen Vlassenroot. London School of Economics and Political Science. Typescript.

Shachar, Ron, and Barry Nalebuff. 1999. "Follow the Leader: Theory and Evidence on Political Participation." American Economic Review 89 (3): 525-47.

Shewfelt, Steven. 2009. "Legacies of War: Social and Political Life after Conflict." Unpublished Ph.D. diss. Yale University Department of Political Science.

Sledge, W. H., J. A. Boydstun, and A. J. Rabe. 1980. "Self-Concept Changes Related to War Captivity." Archives of General Psychiatry 37 (4): 430-43.

Snyder, Jack L. 2000. From Voting to Violence: Democratization and Nationalist Conflict, W. W. Norton \& Company.

Spear, Joanna. 2006. "Disarmament, Demobilization, Reinsertion and Reintegration in Africa." In Ending Africa's Wars: Progressing to Peace, ed. O. F. a. R. May. London: Ashgate.

Tedeschi, Richard G., and Lawrence G. Calhoun. 1996. "The Posttraumatic Growth Inventory.” Journal of Traumatic Stress 9: 45571.

Tedeschi, Richard G., and Lawrence G. Calhoun. 2004. "Posttraumatic Growth: Conceptual Foundations and Empirical Evidence." Psychological Inquiry 15 (1): 1-18.

Tennen, Howard, and Glenn Affleck, eds. 1998. Personality and Transformation in the Face of Adversity, eds. R. G. Tedeschi, C. L. Park, and L. G. Calhoun. Mahwah, NJ: Lawrence Erlbaum.

Thomas, Duncan, Elizabeth Frankenberg, and James P. Smith. 2001. "Lost But Not Forgotten: Attrition and Follow-Up in the Indonesia Family Life Survey." Journal of Human Resources 36 (3): 556 92.

Titeca, Kristof. 2008. "The Spiritual Order of the LRA." In The Lord's Resistance Army: War, Peace and Reconciliation in Northern Uganda, eds. Tim Allen and Koen Vlassenroot. London School of Economics and Political Science. Typescript.

Uhlaner, Carole J. 1989. "Rational Turnout: The Neglected Role of Groups." American Journal of Political Science 33 (2): 390-422.

Utas, Mats. 2003. Sweet Battlefields: Youth and the Liberian Civil War. Uppsala, Sweden: Uppsala University Dissertations in Cultural Anthropology.

Veale, Angela, and Aki Stavrou. 2007. "Former Lord's Resistance Army Child Soldier Abductees: Explorations of Identity in Reintegration and Reconciliation." Peace and Conflict: Journal of Peace Psychology 13 (3): 273-92.

Weinstein, Jeremy M. 2007. Inside Rebellion. Cambridge, MA: Cambridge University Press.

Wessells, Michael. 2006. Child Soldiers: From Violence to Protection. Cambridge, MA: Harvard University Press.

Wilkinson, Steven I. 2004. Votes and Violence: Electoral Competition and Ethnic Riots in India. New York: Cambridge University Press.

Williamson, John 2006. "The Disarmament, Demobilization and Reintegration of Child Soldiers: Social and Psychological Transformation in Sierra Leone." Intervention 4 (3): 185-205.

Wood, Elisabeth J. 2003. Insurgent Collective Action and Civil War in El Salvador. New York: Cambridge University Press. 